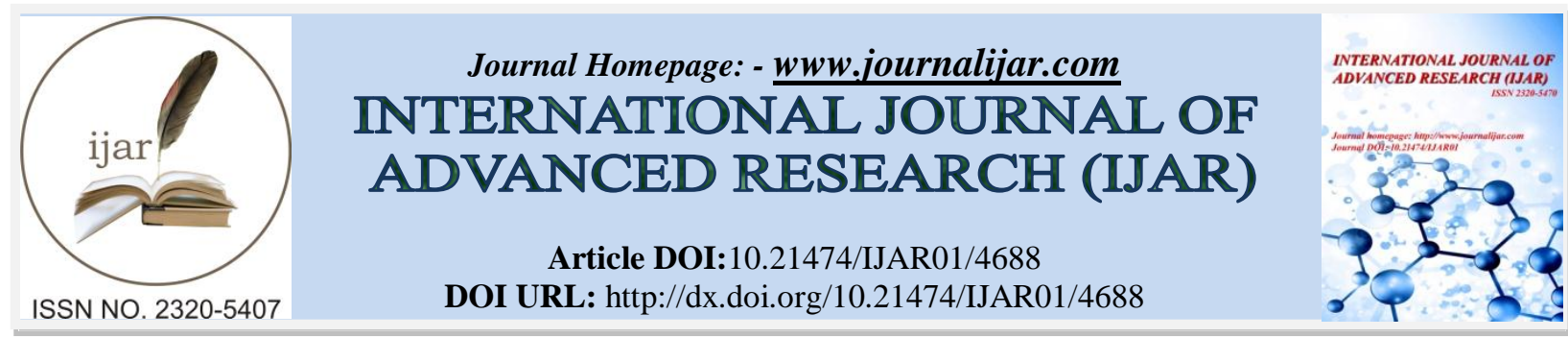

RESEARCH ARTICLE

\title{
ESSENCE OF PRACTICAL TEACHING PRACTICES IN MASTER OF EDUCATION (M.ED.) IN INDIA.
}

\section{Sourav Mahato ${ }^{1}$ Tapas Karmakar $^{2}$ Abhijit Paul ${ }^{3}$ and Manoj Kumar Mahato ${ }^{4}$.}

1. Assistant Professor, Manbhum Institute of Education and Social Science, Purulia, West Bengal, India.

2. Guest Lecturer, Nistarini College, Purulia, West Bengal, India.

3. Assistant Professor, Bidyasagar Foundation School of Education and Training, Purulia, West Bengal, India.

4. Guest Lecturer, Achuram Memorial College, Jhalda, Purulia, West Bengal, India.

\section{Manuscript Info}

\section{Manuscript History}

Received: 1 May 2017

Final Accepted: 3 June 2017

Published: July 2017

Key words:-

Master of Education, Practical Teaching Practices, Micro teaching, Macro

Teaching, Simulation, Practice teaching.

\section{Abstract}

As stated by NCTE (1998), "The teacher is the most important element in any educational programme. It is the teacher who is mainly responsible for implementation of the educational process at any stage." The National Curriculum Framework, 2005 places demands and expectations on the teacher, which need to be addressed by both initial and continuing teacher education. Teacher education is a programme that is related to the development of teacher proficiency and competence that would enable and empower the teacher to meet the requirements of the profession and face the challenges therein. There are two types of teacher education-- pre-service and in-service teacher education. Dl.Ed, B.Ed., M.Ed. and such other programmes are pre-service teacher education. Other hand orientation, refresher course and such other programmes are considered as in-service teacher education. Bachelor of Education (B.Ed.) is the under graduation professional course where as Master of Education (M.Ed.) is the post graduation professional course of teacher education in India. Especially, Master of Education (M.Ed.) is the teacher education programme for the will be teachers of B.Ed. colleges. Also the passed out M.Ed. candidates can teach the students of B.A./B.Sc. in Education, M.A./M.Sc. in Education and M.Ed. students in colleges and universities. But the curriculum of the Master of Education (M.Ed.) includes only the theories of education and research works. There is no scope of practical teaching practices for the teacher-students in this programme. Therefore when they go to teach the students of graduation and master, they face problems to teach. Sometimes they try to use the skills learned in B.Ed. course. But it is wrong operation or not right operation, because the level of the college and university students is different from the level of school students. For this problem, may be, many M.Ed. holder teachers are not successful in job and the quality of bachelor degrees and post graduation degrees in education are not satisfactory. This issue is attempted in this study. The M.Ed. programme has been compared with the current B.Ed. programme of India. Also the M.Ed. programme has been compared with the other different teacher education programmes of different countries. Then it is discussed that 
application of the practical teaching practices such as micro teaching, macro teaching, simulation and practice teaching may be helpful to prepare the M.Ed. teacher-students into successful teachers.

Copy Right, IJAR, 2017,. All rights reserved.

\section{Introduction:-}

As stated by NCTE (1998), "The teacher is the most important element in any educational programme. It is the teacher who is mainly responsible for implementation of the educational process at any stage." This shows that it is imperative to invest in the preparation of teachers, so that the future of a nation is secure. The National Curriculum Framework, 2005 places demands and expectations on the teacher, which need to be addressed by both initial and continuing teacher education.

According to Goods Dictionary of Education 'teacher education' means, "all the formal and non-formal activities and experiences that help to qualify a person to assume responsibilities of a member of the educational profession or to discharge his responsibilities more effectively." The National Council for Teacher Education (NCTE) has defined teacher education as - A programme of education, research and training of persons to teach from pre-primary to higher education level. So we can conclude that teacher education is a programme that is related to the development of teacher proficiency and competence that would enable and empower the teacher to meet the requirements of the profession and face the challenges therein.

Mainly there are two types of teacher education--- pre-service and in-service teacher education. Pre-service teacher education is offered to the candidates who are willing to be teachers. It helps the teacher-student to be a good teacher. In-service teacher education is offered to the teachers who are already working in teaching job. It is offered to make the in-service teachers more efficient and updated. Dl.Ed, B.Ed., M.Ed. and such other programmes are preservice teacher education. Other hand orientation, refresher course and such other programmes are considered as inservice teacher education.

Bachelor of Education (B.Ed.) is the under graduation professional course where as Master of Education (M.Ed.) is the post graduation professional course of teacher education in India. Especially, M.Ed. is the teacher education programme for the candidates who are willing to be teachers in B.Ed. colleges. Also the M.Ed. qualified candidates can teach the students of B.A./B.Sc. in Education, M.A./M.Sc. in Education and M.Ed. in colleges and universities. The curriculum of the Master of Education (M.Ed.) includes only the theories of education and research works. There is no scope of practical activities of teaching for the teacher-students. Therefore when they go to teach the students of graduation and master they face problems to teach. Sometimes they try to use the skills learned in B.Ed. course. But it is not the right operation, because the level of the college and university students is different from the level of school students. For this problem, may be, many M.Ed. holder teachers are not successful in job and the quality of bachelor degrees and post graduation degrees in education are not satisfactory. Therefore it is attempted to discuss are the practical teaching practices such as micro teaching, macro teaching, simulation, practice teaching and such others important in Master of Education.

\section{Rational for the study:-}

The first author taught for one year to the teacher-students of Bachelor of Education (B.Ed.). He took classes on 'problems of teacher education'. During the classes he got the problem that there is absence of practical teaching practices in Master of Education (M.Ed.) such as micro teaching, macro teaching, simulation, practice teaching etc. although these are important for quality teacher education and to prepare the quality teacher educators. He shared the issue with the another friend authors and then prepared a article on the problem with its suggestive solutions.

\section{Operational Definitions of the Key Terms:-}

Master of Education: It is the post graduation pre-service teacher education programme offered in India.

Practical Teaching Practices: It refers the practices of teaching and the parts of teaching in practical. Micro teaching, macro teaching, simulation and practice teaching are the examples.

Micro teaching: It refers the minimization of teaching into skill, time and equipments.

Macro teaching: It is the total teaching in a class, but artificially.

Simulation: It is the artificial teaching where among the teacher-students someone roles as teacher, somebody as students and somebody as supervisors. 
Practice teaching: It is the practical teaching in classroom in any educational institution.

\section{Review of Related Literature:-}

Srivastava (1989) attempted to study the impact of pre-service teacher education program of lucknow university on pupil-teachers attitude and teaching efficiency. The objectives of the study were: (1) to find out the change in teacher attitudes, teacher aptitude and teaching efficiency of teacher-students after the completion of training, (2) to compare the teacher attitude, teacher aptitude and teaching efficiency of teacher-students in respect of sex difference, different teaching subjects, different academic qualifications and different teaching experiences, and (iii) to find out the correlation between teaching efficiency and achievement in the theory papers of the training program. The findings of study were: (1) Most of the trainee groups changed their teacher attitude positively and significantly after training, (2) the experienced male trainees did not show any change in their teacher attitude, (3) there was no significant change in the teacher-aptitude of the male postgraduate student-teachers and the experienced female trainees as a result of the training, (4) all the trainees showed significant and appreciable improvement in their classroom teaching performance, (5) after the completion of the training, the females showed better teacher-attitude and aptitude than the male trainees. Male trainees showed better teaching efficiency than female trainees, and the trainees teaching social sciences showed better teaching efficiency than those teaching science and mathematics.

Behari (1998) conducted a study on Analysis of Pre-service Teacher Education Curriculum in the context of requisite abilities for effective teaching. The study analyzed the teacher education curriculum in relation to develop requisite abilities for effective teaching. The sample consisted of 187 student-teachers enrolled at Central Institute of Education (CIE), University of Delhi (in one session). Student-teachers' ability schedule consisted of a list of abilities categorized into two major areas. Personality characteristics and skills of teaching, covering 40 components were employed for data collection. Findings of study were: - the methodology of teaching paper was more helpful than foundation papers taken together in developing abilities, especially skills, but practice teaching or practical skills in teaching were found to be more helpful than the rest of the teacher education program in developing abilities especially skills. Dramatics as the activity and discussions as a mode of transaction of program were found to be more helpful. It was observed that a theory practice link was missing in teacher education program and therefore the studentteachers were not able to link what they had learnt.

Reddy (2007) found that the majority of the students teachers are favorable attitude towards Micro Teaching $64.5 \%$ of the students teachers were favorable and remaining $34.5 \%$ of the student-teachers are disposing towards Micro Teaching.

Biswas and Das (2011) reported that teacher education plays a crucial role in structuring present systems of society and shaping the future of nation. It has been rightly said that the quality of education and the development aspects in all sectors of a country depend much upon the quality of its teachers. The quality of training imparted to the teachers in the teacher education institutions is quite important in the present context.

Umashree and Kothari (2010) viewed that for a teacher education program to be successful, it is required that the theoretical aspects get internalized through appropriate practical experiences. A conspicuous absence in the present day teacher education program is that of reflective component and has led to the divorce between theory and practice. The colleges are not in a position to equip the future teacher in the latest method, techniques and strategies for imparting instruction including media devices and educational hardware.

Fortune (1965) designed a questionnaire to assess attitudes of students towards micro teaching technique in Stanford summer micro technique clinic. The result was quite encouraging. It was found that 60 percent of the participating students reported their micro teaching experience either very or extremely valuable.

Zayapragassarazan (2007) found that majority of teacher trainees had favorable perception towards teaching practice program. The male and female student-teachers had shown a favorable perception towards teaching practice program. The undergraduate and post-graduate student-teachers had favorable perception of $64 \%$ and 
$65 \%$ respectively. The perception of the rural and urban student-teachers towards teaching practice program was found to be $64 \%$ and $68 \%$ respectively.

Need and significance of practical teaching practices in Master of Education (M.Ed.):-

The need and significance of practical teaching practices in Master of Education are following.

i. To make the M.Ed. teacher-students efficient in teaching, practical teaching practices are very important.

ii. To make the M.Ed. teacher-students confident in teaching and to give experience of teaching to them in graduation and master level, the practices are necessary and important.

iii. The practical teaching practices are very important for the M.Ed. teacher-students so that they can be successful in future teaching life.

iv. The colleges and departments of Education can get the touch of new generation teacher educators during the practice teaching of the M.Ed. teacher-students.

v. Through this programme the M.Ed. teacher-students can apply the knowledge of theories in practical field.

\section{Suggestions:-}

The M.Ed. programme has been compared with the current B.Ed. programme of India. Also it has been judged comparing with the other different teacher education programmes of different countries. Different research works done in India and out of India on teacher education were studied. Different policies and frameworks prepared by different committees and commissions were studied. Then simply it is tried to provide the suggestions to practical teaching practices in Master of Education.

1. Micro teaching could be utilised to teach teaching skills to the M.Ed. teacher-students.

2. Simulation could be utilised to make the M.Ed. teacher-students efficient in teaching.

3. Practice teaching in B.Ed. colleges could be arranged to make the M.Ed. teacher-students efficient in teaching.

4. Lecture method could be taught to the M.Ed. teacher-students though micro teaching, simulation and macro teaching so that they can easily teach the students of graduation and post graduation.

5. Power point presentation technique could be taught to the M.Ed. teacher-students though micro teaching, simulation and macro teaching so that they can easily teach the students of graduation and post graduation.

6. For micro teaching, at least one class per day during a semester ( 5 classes $\times 4$ weeks $\times 5$ months $=100$ classes) could be arranged for quality learning of teaching skills by the teacher-students and for their efficiency in the skills.

7. For Simulation, at least one class per day during a semester ( 5 classes $\times 4$ weeks $\times 5$ months $=100$ classes $)$ could be arranged for quality learning of teaching by the teacher-students.

8. Sufficient macro teaching could be arranged for the teacher-students. At least one class per day during a semester $(5$ classes $\times 4$ weeks $\times 5$ months $=100$ classes $)$ could be arranged to make the teacher-students efficient in classroom teaching.

9. Practice teaching could be arranged in local colleges of teacher education and departments of education during a semester so that at least one class they can take every day ( 5 classes $\times 4$ weeks $\times 5$ months $=100$ classes).

10. Practice teaching could be continued during 1 year for good experience of teaching and to make the teacherstudents efficient in teaching. One experience certificate of teaching could be offered to the teacher-students after one year. It will be reinforcement as well as helpful to them for their academic carrier.

11. Also lesson planning could be used in the practice teaching to maintain scientific procedure of teaching.

12. Action research during practice teaching could be done.

13. Regular inspection and supervision could be done during the practices.

14. Regular evaluation could be done and regular feedback could be given during the practices to create reinforcement to the teacher-students. Also weekly and monthly evaluation could be done and feedback could be given for the same purpose.

15. Final evaluation of the teaching practices could be done by inspectors, supervisors, internals and externals together to maintain the quality.

\section{Conclusion:-}

Practical teaching practices are important in all levels of teacher education. Now these are compulsory for the teacher education programmes of primary, lower secondary and higher secondary levels. Also the practices could be utilised in Master of Education to maintain the quality. 


\section{References:-}

1. Northcote, M. (2009). Educational Beliefs of Higher Education Teachers and Students: Implications for Teacher Education. Australian Journal of Teacher Education.

2. Muralidharan, K. (2011). Performance Pay: Experimental Evidence from India. The Journal of Political Economy.

3. Namung, S. (2012).Teacher education as a driver for sustainable development in Kania. International Journal of Humanities and Social Science.

4. Lim, C. (2009). Innovative Practices in Pre - service Teacher Education. Sense Publication.

5. Glew, M. (2012). Global Teacher Education. Mechigan State University.

6. Cheney, G. (2006). A Profile of the Indian Education System. National Center on Education and the Economy.

7. Fry, H. (2009). A Hand book for Teaching and Learning in Higher Education. Routledge Publication, New York.

8. Koul, L. (2013). Methodology of Educational Research. Vikas Publishing House Pvt Ltd, New Delhi.

9. Innovations and Initiatives in Teacher Education in Asia and the Pacific Region. UNESCO. 1990.

10. National Curriculum Framework for Teacher Education. NCTE, New Delhi, India. 2009.

11. An Anthology of "Best Practices" in Teacher Education. NAAC, Bangalore, Karnataka, India. 2007.

12. Voices of Teachers and Teacher Educators. MHRD, Government of India. 2012.

13. Teacher Development and Management. MHRD, Government of India. 2009.

14. Annual Report, 2014-15. MHRD, Government of India.

15. Education and National Development. Report of the Education Commission, 1964-66.

16. World Education Report. United Nations Educational, Scientific and Cultural Organization (UNESCO).1998.

17. National Knowledge Commission, Report to the Nation, 2006-2009. Government of India.

18. Vision of Teacher Education. MHRD, Government of India. 2012.

19. Sodhganga, Inflibnet, India. 